The BDJ News section accepts items that include general news, latest research and diary events that interest our readers. Press releases or articles may be edited, and should include a colour photograph if possible. Please direct your correspondence to the News Editor, Arveen Bajaj at the BDJ, 64 Wimpole Street WIG 8YS or by email to bdj@bda.org

\section{ARF fees update}

Over 90 per cent of registrants $(31,000)$ have paid their Annual Retention Fee (ARF) and around 30,000 annual practising certificates have been issued, according to the GDC.

About 1,000 registrants have written to ask the Council to remove their names from the register.

The Electoral Reform Services' help line has received over 3,500 telephone calls, with staff at the GDC responding to an additional 2,500 calls.

Several hundred letters have also been received about the ARF - all of which have been responded to.

The GDC adds that an analysis of the letters and calls will be made so that they can determine registrants' main areas of concern. This, along with a full debriefing of this year's ARF exercise, will be reported to the Registration Committee in February.

The Council adds that it is clear from the postbag that the decision to raise the fee for the over-65s has caused considerable controversy and that the unavoidable late issue of practising certificates has also caused concern.

To this end, the Chief Executive of the Registration Department, and Communications will be reviewing the lessons to be learned from this year's ARF exercise, and will be making proposals for the future.

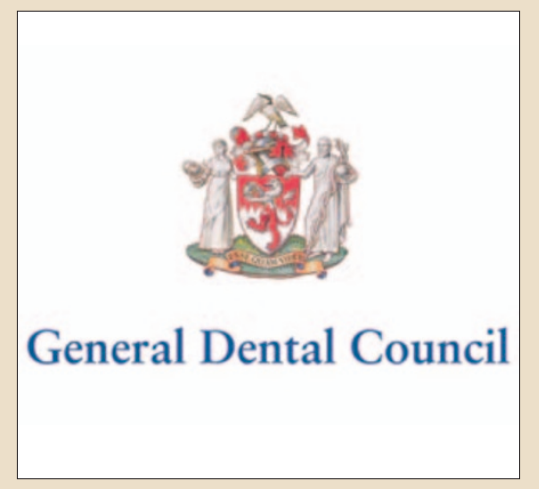

\section{Researchers win award}

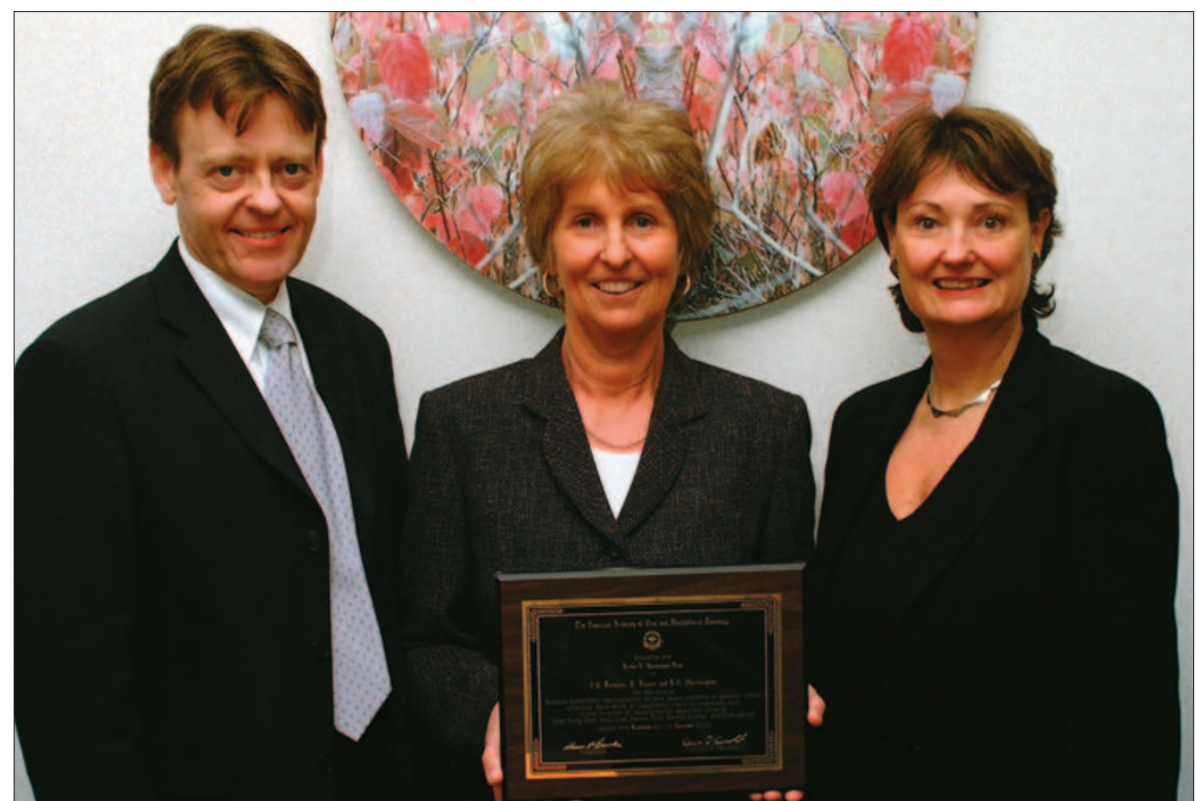

Three Manchester University researchers have been awarded The Wuehrmann Prize by the American Academy of Oral and Maxillofacial Radiology. The award recognises high standards of scientific endeavour and writing and is awarded annually to the authors of the best article published within the Oral Radiology section of the journal Oral Surgery, Oral Medicine, Oral Pathology, Oral Radiology and Endodontics. Dr Vivian Rushton, Senior Lecturer in oral and maxillofacial radiology (centre), Professor Keith Horner, Professor of oral and maxillofacial imaging (left) and Professor Helen Worthington, Professor of evidenced based care (right) received the award for their paper which evaluated the benefits obtained from screening panoramic radiography of adult patients within general dental practice.

\section{European Parliament approves directive}

The European Parliament has accepted amendments to the draft directive on the Mutual Recognition of Professional Qualifications. This will mean that healthcare professionals from any EU country working abroad, may be required to register with the relevant regulatory body in whichever country they are working in.

The Alliance of UK Health Regulators on Europe (AURE) called on MEPs voting in the plenary on 11 February to endorse the vote of the Legal Affairs Committee and ensure that public protection safeguards were maintained. MEPs welcomed the decision as a move towards supporting the free movement of labour while maintaining standards in healthcare.

The membership of the Alliance consists of the General Medical Council, the General Dental Council, the General Optical Council, the General Osteopathic Council, the General Chiropractic Council, the Health Professions Council, the Nursing and Midwifery Council, the Royal Pharmaceutical Society of Great Britain, the General Social Care Council and the Pharmaceutical Society of Northern Ireland. 


\section{DIARY}

\section{April 2004}

Avoiding failures and maximising success in restorative dentistry

Date: 02.04.04

Venue: Tunbridge Wells

Contact: Elisabeth Jarrett

Tel: +44 (0)1892 654384

Email: elisabeth.jarrett@btinternet.com

Medicare India 2004

Date: 06-08.04.04

Venue: Pragati Maidan, New Delhi

Contact: Rob Grant

Tel: +44 (0) 2077238020

Fax: +44 (0) 2077238060

Email: rob.grant@kinexlog.com

www.medicare-expo.com

1st European Conference on Preventive $\&$ Minimally Invasive Dentistry

Date: 16-17.04.04

Venue: Copenhagen

Contact: Conference office

Tel: +4545937028

Fax: +45 45937029

Email:pc@quintessence.dk

\section{May 2004}

British Dental Conference and Exhibition Date: 06-08.05.04

Contact: Delegate Management Services Venue: Bournemouth International Centre (BIC)

Tel: 08701666625 or + 44 (0) 1252

771425 (from overseas)

Fax: 08705228890 or + 44 (0) 1252

771790 (from overseas)

www.bda-events.org

\section{Queen's New Year honours}
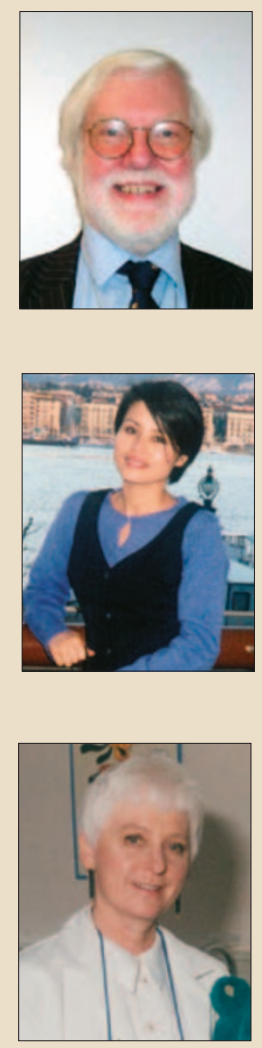

Dental hospital celebrates Golden Jubilee

The Charles Clifford Dental Hospital in Sheffield recently celebrated its Golden Jubilee following 50 years of providing dental services to the people of Sheffield. The Dental Hospital was founded by Colonel Sir Charles Clifford, commander of the Sheffield Territorial Artillery and the 126 Brigade Army field Artillery.

This story was originally printed in BDJ 2003 , 196: 69 with an incorrect picture caption.

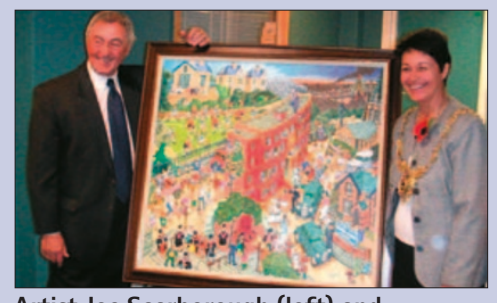

Artist Joe Scarborough (left) and Councillor D. Leek, the Lord Mayor of Sheffield (right) with the Jubilee painting. 


\section{Double recognition gained}

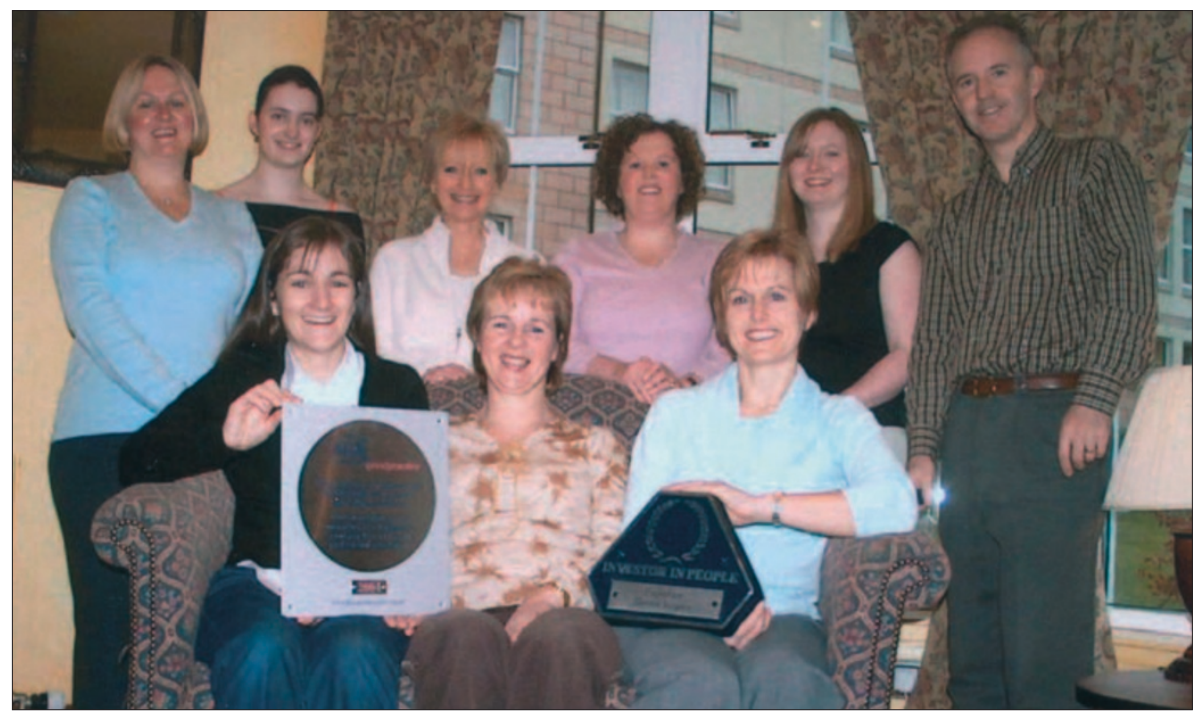

Eaglesham Dental Surgery in Glasgow recently gained both Investor in People recognition and BDA Good Practice accreditation.

\section{Distinguished service to CDA}

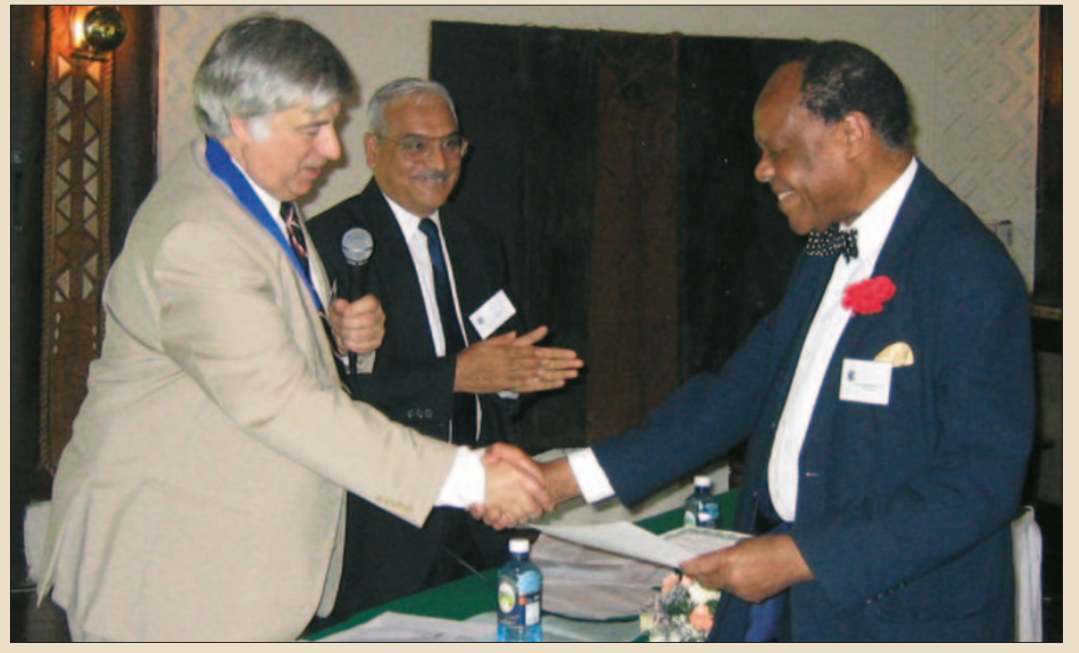

Dr S. Prince Akpabio was given the title of Emeritus Founder President for recognition of his long and distinguished service to the Commonwealth Dental Association (CDA) at its recent 4th Triennial meeting in Kenya. During this meeting Dr L. K. Gandhi was installed as the President of the CDA. (Pictured left to right: Dr Brian Mouatt, former CDA President, Dr L. K. Gandhi, and Dr S. Prince Akpabio).

\section{Women in Dentistry awards}

Women in Dentistry have two annual awards for females in dentistry to which they are inviting entries. The Patricia Nicholls essay prize 2004 of $£ 250$ is for an original essay titled, 'How can I help change patients misconceptions about dentistry?' The essay prize is open to all female dental students and female dentists.

The Caroline Hodge's Bursary of $£ 200$ is available to a female dentist to enable her to further her career. For further details please contact Louise Bligh/Lynn Stevenson, on 02380663414 or email dentists@marchwood.dentalpractice.org.uk.

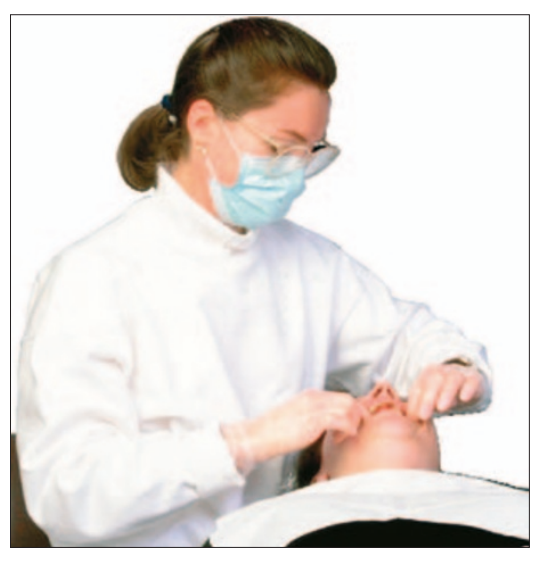

